\title{
Concept Status
}

National Cancer Institute

\section{Source}

National Cancer Institute. Concept Status. NCI Thesaurus. Code C43633.

The standing of a concept in relation to currently accepted classifications and concepts.

In NCl Thesaurus and $\mathrm{NCl}$ Metathesaurus, concept status subtypes are linked to

concepts with unusual and problematic characteristics that should be evaluated by people and/or programs before those concept are used. -- 2004. 